\title{
The flexural behavior model of bamboo reinforced concrete beams using a hose clamp
}

\author{
Muhtar ${ }^{1,2, *}$, Sri Murni Dewi ${ }^{2}$, Wisnumurti ${ }^{2}$, and $A s^{\prime}$ ad Munawir $^{2}$ \\ ${ }^{1}$ Department of Civil Engineering, Universitas Muhammadiyah Jember, Jember, Indonesia \\ ${ }^{2}$ Department of Civil Engineering, Universitas Brawijaya, Malang, Indonesia
}

\begin{abstract}
Bamboo can use at the simple concrete construction because of the tensile strength of its mechanical property. Meanwhile, a slippery surface of the bamboo caused cracks in the bamboo reinforced concrete beam (BRC) not to spread and yield slip failure between a bamboo bar and concrete. Load test at the BRC beam yield humble load capacity. This study aims to improve the capacity and behavior of BRC beam bending by giving waterproof coating, sand, and hose clamp installation. The beam test specimen with the size of $75 \times 150 \times 1100 \mathrm{~mm}$ made as many as 26 pieces with the variety of reinforcement. The hose clamp used on the bamboo reinforcement varies with a distance of $0 \mathrm{~cm}, 15 \mathrm{~cm}, 20 \mathrm{~cm}$, and $25 \mathrm{~cm}$. The testing using a simple beam with two-point loading. The test results show that BRC beams have different bending behavior compared to the steel reinforced concrete beam (SRC).
\end{abstract}

\section{Introduction}

Bamboo can use as a substitute for steel reinforcement in concrete construction, especially for simple construction. The tensile strength of bamboo can reach $370 \mathrm{MPa}$ [1]. Bamboo is much cheaper than steel reinforcement for the same level of strength. Bamboo is easy to obtain, easy to plant, can grow quickly, environmentally friendly, and as a renewable natural resource [2]. Bamboo for construction materials age at least 3-5 years old from the planting period [3] and can be harvested for several time without a need to plant again. Flexural strength of bamboo lamination is stronger if compare to concrete or other natural composite material [4]. The non-treated flexural bamboo reinforcement for reinforced concrete beams is recommended to use a safety factor of 1.2 [5]. Pillars, bridge framework, soil retaining wall in rural societies environment, and the research of reinforcement of peat soil under embankment are also using non-treated bamboo [6]. The slippery surface is the weakness of the bamboo bar. The roughness modifications such as giving notch and wire coil have done, but it hasn't been able to maximize the result.

Waterproof coating, sand coating, and adding a hose clamp on bamboo reinforcement is similar to the concept of deformed steel bars in concrete [7], namely the interaction of friction force, and the support style between steel bars and concrete. The stress and strain

\footnotetext{
*Corresponding author: muhtar@unmuhjember.ac.id
} 
distribution analysis of flexural beam elements by Ghavami [1] is shown at different stages as in Fig. 1.

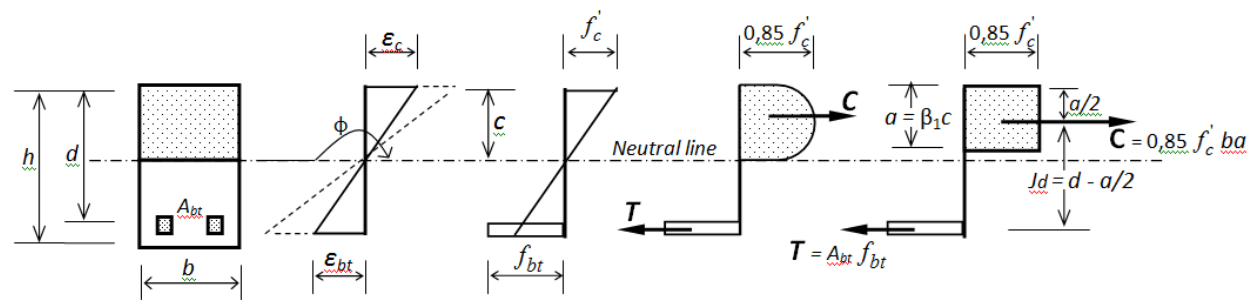

Fig. 1. Distribution of stress-strain cross section of bamboo reinforced concrete blocks [1].

The friction strength or bond stress, $\tau_{b}$ of the bamboo pullout test can be calculated using Eq. (1) [8]:

$$
\tau_{b}=\frac{\mathrm{P}}{(2 a+2 b) L_{a}}\left(\mathrm{~N} / \mathrm{mm}^{2}\right)
$$

with $\mathrm{P}$ is the pullout force, $(2 \mathrm{a}+2 \mathrm{~b})$ is the dimension of the bamboo cross-section, and $L_{a}$ is the length of bamboo surface attachment.

\section{Materials and methods}

\subsection{Bamboo}

This research using bamboo petung (Dendrocalamus Asper) aged between 3-5 years [3] along 6 meters from the base of bamboo stems. Bamboo immersed in water to remove starch content for approximately 30 days [9]. Then bamboo is dried in free air for approximately 30 days [3, 4, 8-11]. Bamboo reinforcement size is $7 \times 10 \mathrm{~mm}^{2}, 10 \times 10 \mathrm{~mm}^{2}$, and $15 \times 15 \mathrm{~mm}^{2}$. The bamboo specimen size $15 \mathrm{~mm}$ thick with a length of $300 \mathrm{~mm}$.

\subsection{Hose clamp and Sikadur ${ }^{\circledR}-752$}

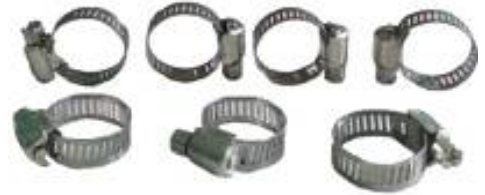

Fig. 2. Hose-clamp ring.

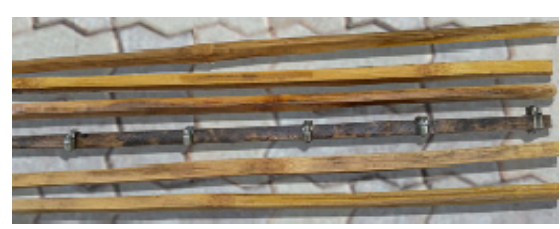

Fig. 3. Bamboo bars with waterproof and sand coating, and the hose clamp.

This research using waterproof coating Sikadur ${ }^{\mathbb{R}}-752$ and $3 / 4$ " stainless-steel hose clamp as shown in Fig. 2 [12, 13]. Hose clamp mounting distance varies between $0 \mathrm{~cm}, 15 \mathrm{~cm}, 20$ $\mathrm{cm}$, and $25 \mathrm{~cm}$. Installation of a hose clamp on the bamboo reinforcement done after the first layer of waterproof coating is dry (Fig. 3). A second waterproof coating is performed for closing first stage waterproof defects and to adhere hose clamp more closely to the bamboo reinforcement, and it sprinkled with sand to become rough [8]. 


\subsection{Test Method}

The test material uses Portland pozzolana cement, sand, coarse aggregate, and water with a proportion of $1: 1.81: 2.82: 0.52$. The compressive strength test carried out using a $150 \times 300 \mathrm{~mm}$ of the concrete cylinder and The Universal Testing Machine (UTM) with 2000 $\mathrm{kN}$ capacity. A pullout test of the bamboo bar using UTM with $500 \mathrm{kN}$ capacity.

The beam test specimen was made as many as 26 pieces with the size of $75 \times 150 \times 1100 \mathrm{~mm}$ (Fig. 4), consist of 24 pieces of BRC beam, one piece of SRC beam, and one concrete beam without reinforcement (PC). Bamboo reinforcement is installed as tensile reinforcement with a variation of reinforcement area $140 \mathrm{~mm}^{2}, 200 \mathrm{~mm}^{2}$, and 450 $\mathrm{mm}^{2}$. The $8 \mathrm{~mm}$ steel bars used with an As $=100.48 \mathrm{~mm}^{2}$ of reinforcement area.

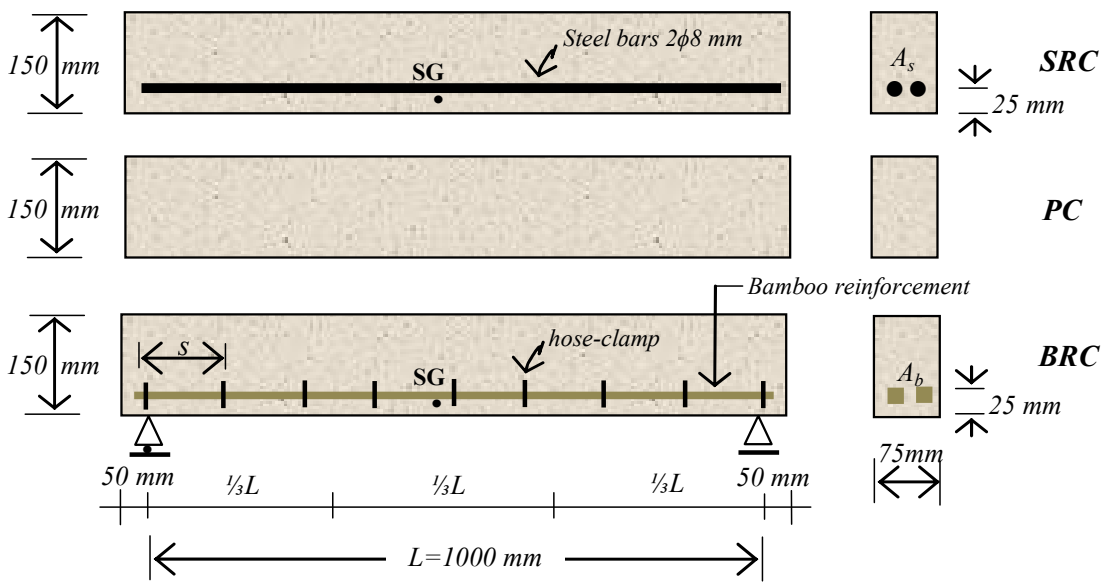

Note: $S R C=$ Steel Reinforced Concrete, $P C=$ Plain Concrete, $B R C=$ Bamboo Reinforced Concrete, $\mathrm{SG}=$ Strain Gauge, $s=$ Distance of hose-clamp (Variation of $s=0 \mathrm{~cm}, 15 \mathrm{~cm}, 20 \mathrm{~cm}$, and $25 \mathrm{~cm}$ ), $A_{s}=$ Area of steel reinforced $\left(A_{s}=100.48 \mathrm{~mm}^{2}\right), A_{b}=$ Area of bamboo reinforced (Variation of $A_{b}=140 \mathrm{~mm}^{2}, 200 \mathrm{~mm}^{2}$, and 450 $\mathrm{mm}^{2}$ ).

Fig. 4. Detail and geometry of the bamboo reinforced concrete beam.

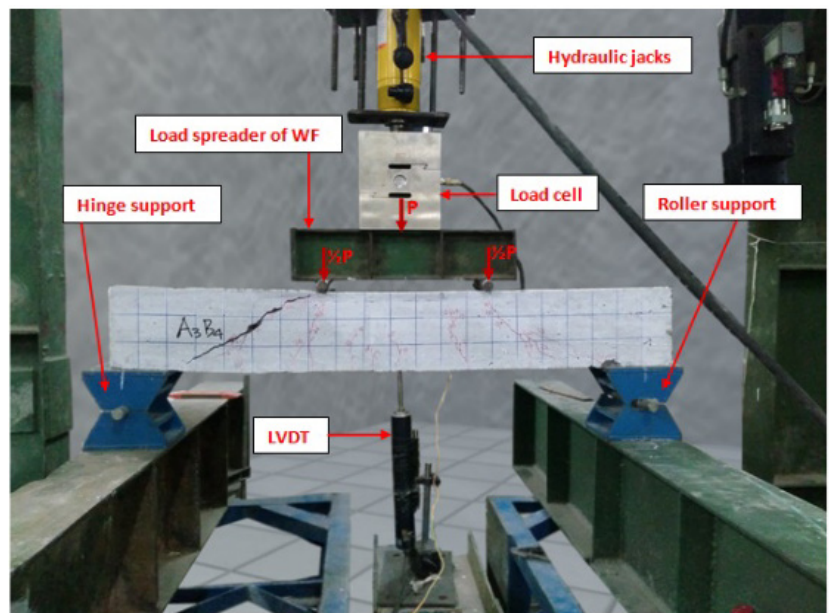

Fig. 5. The flexural test of bamboo reinforced concrete.

The flexural test is carried out using a two-point loading method on simple beam [14]. External load divided into two points with spaced $1 / 3 \mathrm{~L}$ from the beam support with a WF load spreader. The strain gauge mounts on the bamboo bar at $1 / 2 \mathrm{~L}$ from the beam support. 
Deflection is detected using LVDT (Linear Variable Displacement Transducers) at a $1 / 2 \mathrm{~L}$ distance from the beam support. External load provided using hydraulic jack and $200 \mathrm{kN}$ load cell. Deflection control becomes the controller after beam reaches its ultimate load. The settings of the applied test equipment and load scheme shown in Fig. 5.

\subsection{Verification by finite element method}

Numerical verification is done using the finite element method with the Fortran PowerStation 4.0 program. The load that caused the initial crack is calculated using elastic theory (linear analysis) with the transformation cross-section. For linear analysis, the material data included is the modulus of elasticity (E) and the poisons ratio (v). Triangular elements are using to model plane stress elements in two directions of primary displacements $(\mathrm{u}, \mathrm{v})$ at each point so that the element has six degrees of freedom. The discrete form of the beam with the triangular element shown in Fig. 6.

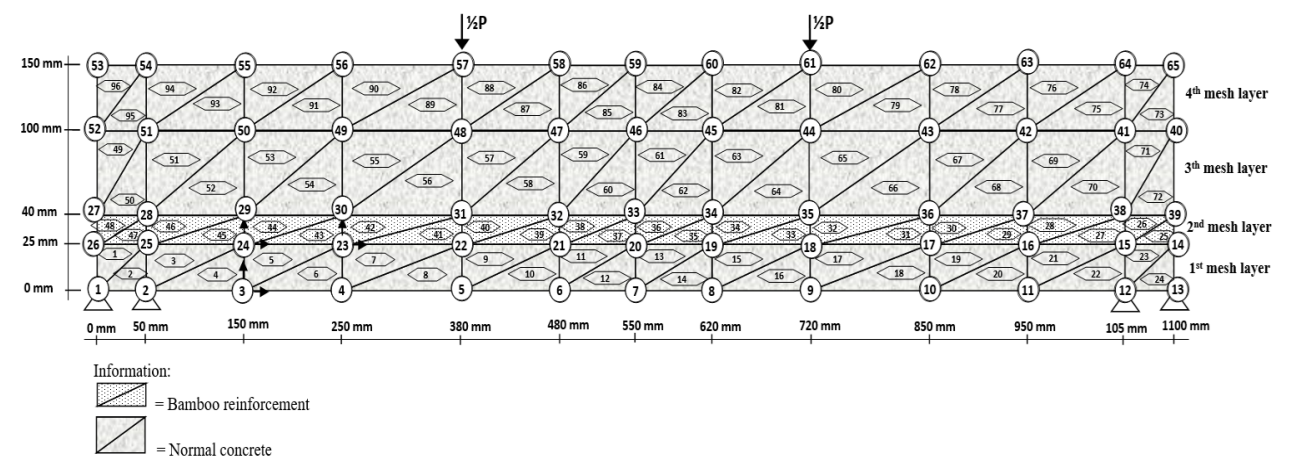

Fig. 6. Finite element idealization of BRC beam.

\section{Results and discussion}

\subsection{Pull out tests results}

From pull-out test results, bamboo reinforcement with a coating of Sikadur ${ }^{\circledR}-752$, sand, and hose clamp embedded in concrete cylinders showed an increase of bond stresses of $240 \%$ and $214 \%$ compared to untreated bamboo, with hose-clamp spacing respectively $15 \mathrm{~cm}$ and $20 \mathrm{~cm}$. For untreated bamboo reinforcement with hose clamp distance of $10 \mathrm{~cm}$, the bond stress increased $8 \%$. While bamboo reinforcement with Sikadur ${ }^{\circledR}-752$ coating and sand without hose clamp increased by $150 \%$ as shown in Fig. 7.

The specimen which treated using a waterproof and sand coating and hose clamp shows the bond collapse patterns and concrete cone failure and bamboo node failure as shown in Fig. 8b and Fig. 8c. This shows the Sikadur ${ }^{\mathbb{B}}-752$ adhesive effect and the hose clamp installation work well, and the concrete still attaches to the bamboo reinforcement. The specimen with sand and Sikadur ${ }^{\circledR}-752$ coating shows bond-slip failure but still has an excellent high adhesive strength. While the specimen with only hose clamp shows bondslip failure almost the same as bamboo reinforcement without treatment as shown in Fig. $8 \mathrm{a}$. The test results show that waterproof and sand coating is necessary before the hose clamp installation. 


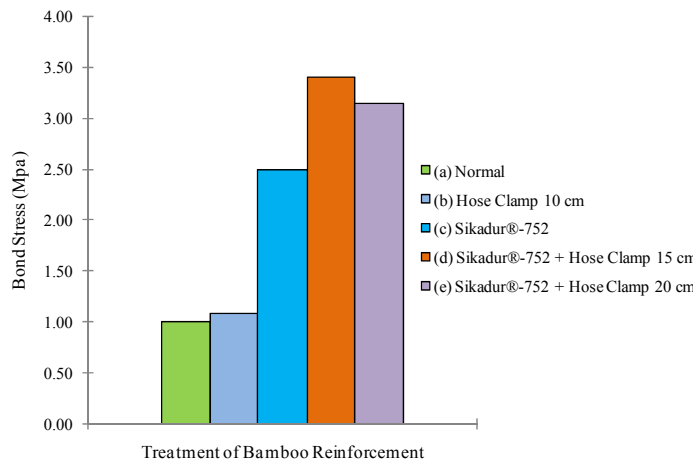

Fig. 7. Variation of the bamboo bond stress.

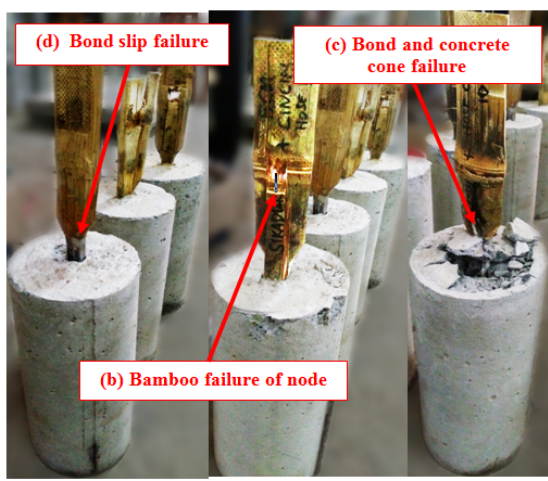

Fig. 8. The failure mode of the pullout test.

\subsection{Flexural beam test}

\subsubsection{The capacity of the bamboo reinforced concrete beam}

Fig. 9 shows the average ultimate load of BRC beam with hose clamp reaches $90 \%$ more than theoretical calculation. This is one of the problem solutions of the low capacity of bamboo reinforced concrete beams. Earlier researchers concluded that the bending capacity of bamboo reinforced concrete beams only reached $56 \%$ of its capacity if full bamboo tensile strength [15], reaching only $29 \%$ to $39 \%$ of the steel reinforced concrete beam capacity with the same dimensions and breadth area [16], and just reached $35 \%$ of steel reinforced concrete beams at the same level of strength [17, 18].

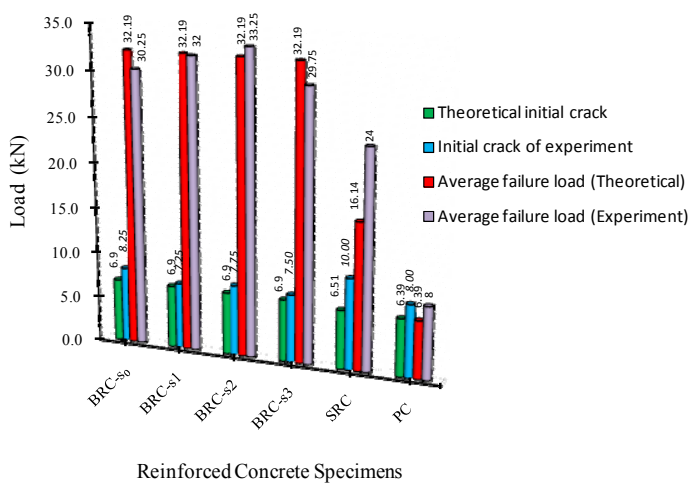

Fig. 9. Comparison of BRC beam ultimate loads.

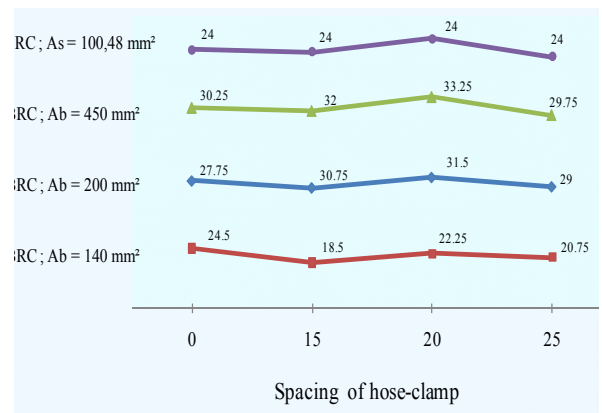

Fig. 10. The ultimate load of BRC beams based on reinforcement area variation and hose clamp distance.

Fig. 10 shows the ultimate load of BRC beam with hose clamp is higher up to $38.5 \%$ compared to SRC beam with area $100.48 \mathrm{~mm}^{2}$. BRC beams with $1.78 \%$ bamboo reinforcement area have surpassed the strength of SRC beams with a steel reinforcement area of $0.89 \%$ up to $38.54 \%$. The greater bamboo reinforcement area ratio will increase the capacity of the BRC beam in a linear trend. Variation of hose clamp usage on BRC beams can increase load capacity up to $35.71 \%$ compared to BRC beams without hose clamp. Optimum hose clamp installation occurs on BRC beams with a $20 \mathrm{~cm}$ distance with an 
ultimate load of $33.25 \mathrm{kN}$. The largest ultimate load capacity achieves by BRC beam with reinforcement ratio $(\rho) 4 \%$ or reinforcement area $450 \mathrm{~mm}^{2}$ with a hose-clamp distance 20 $\mathrm{cm}$. BRC beam load capacity with bamboo reinforcement ratio $(\rho) 4 \%$ and hose clamp distance $0 \mathrm{~cm}, 15 \mathrm{~cm}, 20 \mathrm{~cm}$, and $25 \mathrm{~cm}$ increase respectively $26.04 \%, 33.33 \%, 38.54 \%$, and $23.96 \%$ compare to SRC beam with reinforcement ratio steel $0.89 \%$.

\subsubsection{The load-deflection relationship.}

Fig. 11 and Fig. 13 illustrate the load-deflection relationship and the stress-strain relationship of the BRC beam and the SRC beam. In the SRC load-deflection diagram, load-deflection connections are trilinear, i.e.: (i) the pre-crack area, (ii) the post-crack area, and (iii) the crack area (post-serviceability).

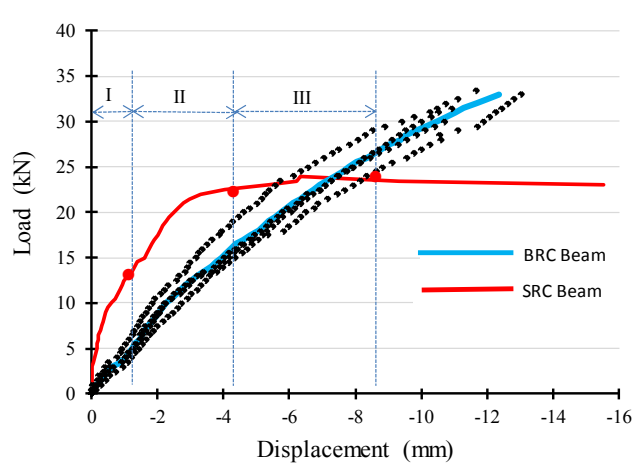

Fig. 11. The behavior of loaddeflection BRC beam and SRC beam.

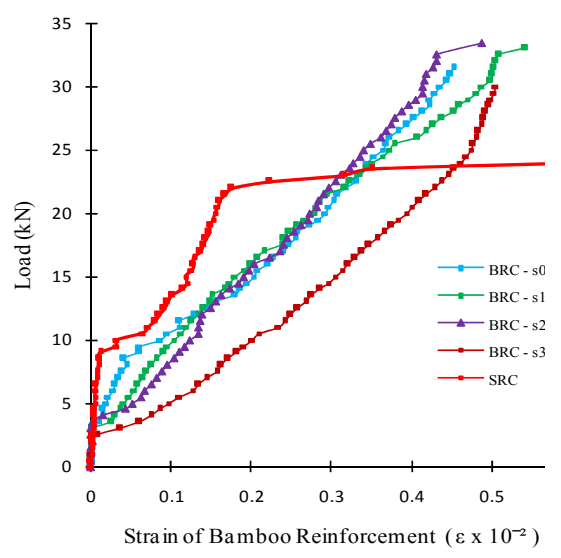

Fig. 13. Load-strain correlation of $\mathrm{BRC}$ beam.

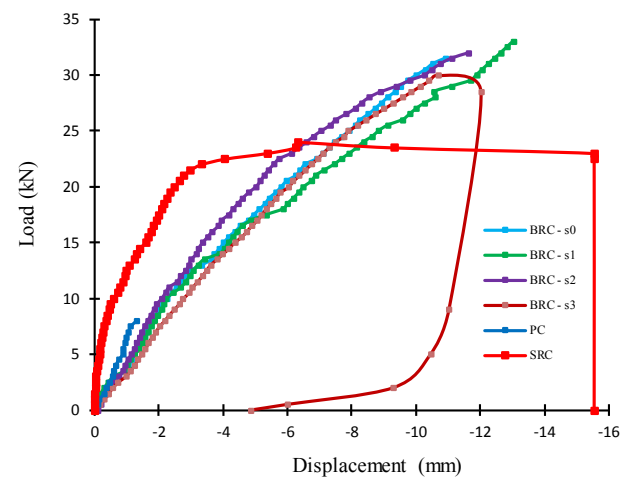

Fig. 12. BRC beam load-deflection diagram.

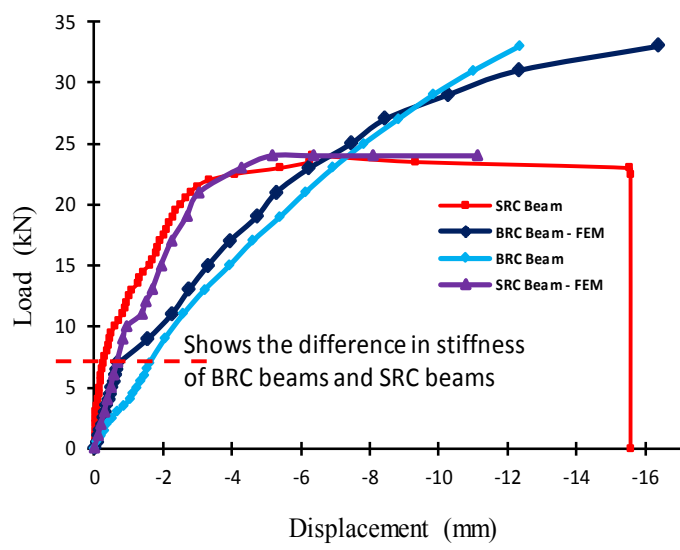

Fig. 14. The behavior of load-deflection relation of $\mathrm{BRC}$ beam and SRC beam with finite element method.

While the load-deflection diagram of BRC beam shows only the pre-crack or elastic region. The post-crack area until the crack area (post-serviceability) tends to be linear. The BRC beam load-deflection diagram has a much higher deflection compared to SRC beam before failure, indicating higher energy absorption and ductility. BRC beam after reaching ultimate load or after crack level, if the load releases, the deflection almost return to zero as shown 
in Fig. 12. As an example of the BRC-s3 beam deflection behavior in Fig. 12. While the SRC beam, after ultimate load, the deflection diagram will increase without load increment until collapse occurs.

In Fig. 14, if the horizontal line is portraying the point where the initial crack occurs the BRC beam, it will explain that the stiffness of the BRC beam is lower when compared to the stiffness of the SRC beam. The average value of BRC beam stiffness is lower to $75 \%$ than the SRC beam. This is the weakness of BRC beams that need to be examined in further studies. The diagram shows that the decreased stiffness after the initial crack following the loading stages of each mesh layer is very influential on the results of the analysis performed. The modulus of elasticity of concrete on BRC beam was reduced from 26,324.76 MPa before cracking to 6581.20 MPa after collapsed [19].

\subsubsection{Load-deflection correlation model of bamboo reinforced concrete beams}

Table 1. Load-displacement relationship calculation data.

\begin{tabular}{|c|c|c|c|c|c|c|c|c|}
\hline \multirow[b]{2}{*}{$\begin{array}{l}\text { Specimens/ } \\
\text { code }\end{array}$} & \multirow[b]{2}{*}{$\begin{array}{c}\text { Sample } \\
\text { no }\end{array}$} & \multicolumn{2}{|c|}{$\begin{array}{l}\text { Theoretical } \\
\text { calculations }\end{array}$} & \multicolumn{5}{|c|}{ Flexural test results } \\
\hline & & $\begin{array}{c}\text { First } \\
\text { crack } \\
\text { load } \\
(\mathrm{kN})\end{array}$ & $\begin{array}{c}\text { Ultimate } \\
\text { load } \\
(\mathbf{k N})\end{array}$ & $\begin{array}{c}\text { First } \\
\text { crack } \\
\text { load, } \\
\boldsymbol{P}_{c r}(\mathbf{k N})\end{array}$ & $\begin{array}{c}\text { Service } \\
\text { load, } \\
P_{\text {service }} \\
(\mathbf{k N})\end{array}$ & $\begin{array}{c}\text { Failure } \\
\text { load, } \\
P_{\text {ultimate }} \\
(\mathbf{k N})\end{array}$ & $\begin{array}{l}\text { Deflection } \\
\text { at failure } \\
(\mathrm{mm})\end{array}$ & $\begin{array}{c}\boldsymbol{P}_{c r} / \\
\boldsymbol{P}_{\text {ultimate }} \\
(\%)\end{array}$ \\
\hline \multirow{2}{*}{$\begin{array}{l}\text { (a) } \mathrm{BRC}-\mathrm{s} 0 / \\
\mathrm{A} 3 \mathrm{~B} 1\end{array}$} & 1 & \multirow{2}{*}{6.87} & \multirow{2}{*}{32.19} & 8.50 & 18.90 & 31.5 & 10.92 & 26.98 \\
\hline & 2 & & & 8.00 & 17.40 & 29 & 11.9 & 27.59 \\
\hline \multirow{2}{*}{$\begin{array}{l}\text { (b) BRC-s1/ } \\
\text { A3B2 }\end{array}$} & 1 & \multirow{2}{*}{6.87} & \multirow{2}{*}{32.19} & 7.00 & 18.60 & 31 & 13.02 & 22.58 \\
\hline & 2 & & & 7.50 & 19.80 & 33 & 12.18 & 22.73 \\
\hline \multirow{2}{*}{$\begin{array}{l}\text { (c) BRC-s2/ } \\
\text { A3B3 }\end{array}$} & 1 & \multirow{2}{*}{6.87} & \multirow{2}{*}{32.19} & 8.00 & 20.10 & 33.25 & 14.69 & 23.88 \\
\hline & 2 & & & 7.50 & 19.80 & 33 & 9.32 & 22.73 \\
\hline \multirow{2}{*}{$\begin{array}{l}\text { (d) BRC-s3/ } \\
\text { A3B4 }\end{array}$} & 1 & \multirow{2}{*}{6.87} & \multirow{2}{*}{32.19} & 7.50 & 17.70 & 29.5 & 7.61 & 25.42 \\
\hline & 2 & & & 7.50 & 18.00 & 30 & 10.69 & 25.00 \\
\hline $\begin{array}{l}\text { Mean values } \\
(R u)\end{array}$ & & & & 7.69 & 18.79 & 31.31 & 11.29 & 24.61 \\
\hline $\begin{array}{l}\text { Standard } \\
\text { deviation }(\sigma)\end{array}$ & & & & 0.46 & & 1.73 & & 1.97 \\
\hline
\end{tabular}

A load-deflection pattern of BRC and SRC beams are influenced by the mechanical properties of the reinforcement. The stress-strain characteristics of bamboo do not have a long starting yielding point. This causes the service load limit point is difficult to determine. The service load range limits are determined at the base of ASTM E2126 [20] i.e. by drawing a vertical line through the line encounter of 0.4 Pultimit with a horizontal line of 0.8 Pultimit. BRC beam load-deflection diagram analysis shows the average $\mathrm{P}$ service load of $18.79 \mathrm{kN}$ or about $60 \%$ of Pultimate. While the value of the elastic boundary point range is calculated using the Eq. 2 : 


$$
\begin{gathered}
P_{c r} / P_{\text {ultimate }}=R_{\mathrm{u}}-2.3(\sigma) \\
P_{c r} / P_{\text {ultimate }}=R_{\mathrm{u}}-2.3(\sigma)=20.07 \% \approx 20 \% .
\end{gathered}
$$

Table 1 shows that the lowest elastic point of $22.58 \%$ occurs on the BRC-s1 beam, the highest of $27.59 \%$ occurring on the BRC-s0 beam. The average of the elastic limit point is $24.61 \%$ of the ultimate load. The elastic boundary value is $20 \%$ of the ultimate load. The elastic point limit on the SRC beam is $41.67 \%$ of the ultimate load. The service load range is $60 \%$ of the ultimate load. The idealization of the BRC beam load-deflection model shown in Fig. 15.

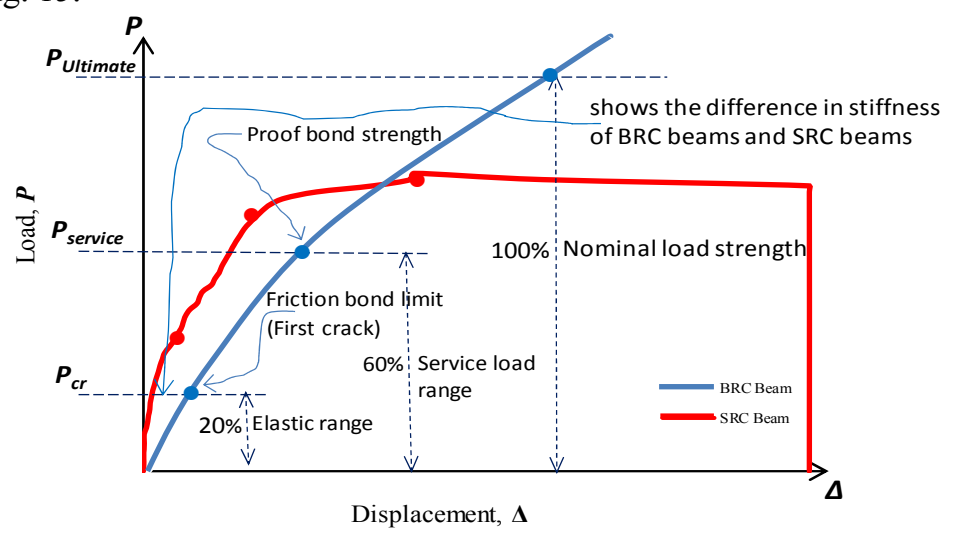

Fig. 15. The idealization of the load-displacement relationship model of BRC beam.

\section{Conclusions}

Installation of hose clamps, waterproof coatings, and sandblasting on reinforcement of BRC beams as slip brackets between bamboo reinforcement and concrete can increase the capacity of BRC beams, but still, have much lower stiffness than SRC beam stiffness. The reduction of elastic constants in each blocking layer is applying to analyze the loaddeflection relationship of BRC beams. The result of the analysis shows that the loaddeflection analysis model is quite close to the experimental results.

In the load-deflection diagram model of SRC beam, the relationship is trilinear, i.e. i) the pre-crack area, ii) the post-crack area, and iii) the crack area (post-serviceability). While on the BRC beam shows only the pre-crack or elastic region. The post-crack area until the crack area (post-serviceability) tends to be linear.

The research described in this paper financially supported by Domestic Postgraduate Education Scholarship (BPP-DN), located in University of Brawijaya, Malang, Indonesia.

\section{References}

1. K. Ghavami, Cem. Con. Comp. 27, 6 (2005)

2. C. Sabnani, M.V Latkar, U. Sharma, Int. J. Civil, Env. Struct. Constr. Arch. Eng. 6, 11 (2012)

3. A. Agarwal, B. Nanda, D. Maity, Con. Build. Mat. 71 (2014)

4. B. Sharma, A. Gatóo, M. Bock, M. Ramage, Con. Build. Mat. 81 (2015)

5. A. Gisleiva, C.S. Ferreira, A.L. Beraldo, A.L. Moreno Jr. Ottoni, Int. J. Sustain. Mat. 
Struct. Syst. 2 (2016)

6. M. Azwar, R.D. Susanti, A. Waruwu, ARPN J. Eng. Appl. Sci. 13, 1 (2018)

7. S. Islam, H.M. Afefy, K. Sennah, H. Azimi, Con. Build. Mat. 83 (2015)

8. A. Javadian, M. Wielopolski, I.F.C. Smith, D.E. Hebel, Con. Build. Mat. 122 (2016)

9. H. Frick, Ilmu bahan bangunan (Kanisius \& Soegipranata University Press, Semarang, 1999)

10. E. Ikponmwosa, C. Fapohunda, O. Kolajo, O. Eyo, J. King Saud Univ. Eng. Sci. 29, 4 (2017)

11. S. Karthik, P.R.M. Rao, P.O. Awoyera, J. King Saud Univ. Eng. Sci. 29, 4 (2017)

12. Muhtar, S.M. Dewi, Wisnumurti, A. Munawir, Proc. $2^{\text {nd }}$ Int. Multidiscip. Conf. (2016)

13. Muhtar, S.M. Dewi, Wisnumurti, A. Munawir, Int. J. Civ. Eng. Tech. 9, 8 (2018)

14. ASTM, Standard Test Method for Flexural Strength of Concrete (Using Simple Beam with Third-Point Loading) ASTM C78/C78M (ASTM International, West Conshohocken, 2002)

15. S.M. Dewi, D. Nuralinah, MATEC Web of Conferences 103, 02001 (2017)

16. S. Nathan, Application of bamboo for flexural and shear reinforcement in concrete beams (Clemson University, South Caroline, 2014)

17. L. Khare, Performance evaluation of bamboo reinforced concrete beams (The University of Texas, Arlington, 2005)

18. K. Terai, Masakazu, Minami, World Conf. Earthq. Eng. (2012)

19. ACI, Building Code Requirements for Structural Concrete ACI 318M-14 (American Concrete Institute, Farmington Hill, 2014)

20. ASTM, Standard Test Methods for Cyclic (Reversed) Load Test for Shear Resistance of Vertical Elements of the Lateral Force Resisting Systems for Buildings ASTM E2126 (ASTM International, West Conshohocken, 2015) 